\title{
Effects of dietary protein levels on growth performance and body composition of juvenile parrot fish, Oplegnathus fasciatus
}

\author{
Kang-Woong Kim $\cdot$ Mohammad Moniruzzaman $\cdot$ Kyoung-Duck Kim $\cdot$ \\ Hyon Sob Han $\cdot$ Hyeonho Yun $\cdot$ Seunghan Lee $\cdot$ Sungchul C. Bai
}

Received: 9 March 2016/Accepted: 13 July 2016/Published online: 20 July 2016

(C) The Author(s) 2016. This article is published with open access at Springerlink.com

\begin{abstract}
The present study was conducted to evaluate the effects of dietary protein levels on growth, biometrics, hematology and body composition in juvenile parrot fish Oplegnathus fasciatus. Fish averaging $7.1 \pm 0.06 \mathrm{~g}$ (mean $\pm \mathrm{SD}$ ) was randomly distributed into 15 net cages (each size: $60 \times 40 \times 90 \mathrm{~cm}$, $\mathrm{W} \times \mathrm{L} \times \mathrm{H})$ as groups of 20 fish. Five isocaloric diets $(16.7 \mathrm{~kJ} / \mathrm{g}$ energy) were formulated to contain crude protein levels $(\mathrm{CP})$ as $35\left(\mathrm{CP}_{35}\right), 40\left(\mathrm{CP}_{40}\right), 45\left(\mathrm{CP}_{45}\right), 50\left(\mathrm{CP}_{50}\right)$ and $60 \%\left(\mathrm{CP}_{60}\right)$ in the diets. Fish were fed one of the experimental diets at apparent satiation twice a day in triplicate groups. At the end of 8 -week feeding trial, weight gain (WG) of fish fed with $\mathrm{CP}_{50}$ and $\mathrm{CP}_{60}$ diets were significantly higher than those of fish fed with $\mathrm{CP}_{35}, \mathrm{CP}_{40}$ and $\mathrm{CP}_{45}$ diets. Fish fed with $\mathrm{CP}_{45}, \mathrm{CP}_{50}$ and $\mathrm{CP}_{60}$ diets had higher feed efficiency (FE) and specific growth rate (SGR) than those of fish fed with $\mathrm{CP}_{35}$ and $\mathrm{CP}_{40}$ diets. Protein retention efficiency (PRE) decreased with increase of dietary protein levels among fish fed with the experimental diets. Wholebody crude protein and lipid contents increased with the dietary protein level up to $\mathrm{CP}_{50}$ diet. In conclusion, analysis of variance (ANOVA) revealed that the optimum dietary protein level could be $50 \%$ for maximum growth of juvenile parrot fish, while the broken-line analysis of WG suggested that the level could be $48.5 \%$, in a diet containing $16.7 \mathrm{~kJ} / \mathrm{g}$ energy.
\end{abstract}

Keywords Optimum protein level $\cdot$ Growth $\cdot$ Hematology $\cdot$ Broken-line analysis $\cdot$ Cages $\cdot$ Parrot fish

\section{Introduction}

Protein is the major macronutrient in fish which provides essential and non-essential amino acids for protein synthesis and energy for maintenance and growth (Kim et al. 2002). However, protein is the most expensive component in fish feed (NRC 1993; Mohseni et al. 2013). For successful aquaculture practices, it is needed to determine the minimum level of protein at which fish can attain maximum growth as well as the operational costs can be saved (NRC 2011). It is well documented that dietary protein requirements for most of the fish species are found to be between 30 and $55 \%$ of the diet; however, it depends on the fish species, fish size, dietary protein sources and environmental conditions (Hepher 1988; NRC 1993).

K.-W. Kim · K.-D. Kim · H. S. Han

Aquafeed Research Center, National Institute of Fisheries Science (NIFS), Pohang 791-923, Korea

M. Moniruzzaman $\cdot$ H. Yun $\cdot$ S. Lee $\cdot$ S. C. Bai $(\bowtie)$

Department of Marine Bio-Materials and Aquaculture, Feeds and Foods Nutrition Research Center, Pukyong National

University, Busan 608-737, Korea

e-mail: scbai@pknu.ac.kr 
Parrot fish, Oplegnathus fasciatus, is one of the important commercial marine finfish species cultured in cages in Korea as well as in East Asia (Meng et al. 1995). In 2015, total production of parrot fish in Korea was approximately 1150 metric tons $(\mathrm{mt})$ where its cage aquaculture contributed $1050 \mathrm{mt}$ (National Statistical Office 2015). It has high market value and consumer demand. Despite the economic value, very little information is available on the nutritional requirements of parrot fish. This study was conducted to determine the optimum dietary protein level in diets for juvenile parrot fish at a specific dietary energy level.

\section{Methods}

Experimental diets

Five experimental diets using white fish meal and casein as the basic protein sources were prepared with protein levels of 35, 40, 45, 50 and $60 \%$ which were designated as $\mathrm{CP}_{35}, \mathrm{CP}_{40}, \mathrm{CP}_{45}, \mathrm{CP}_{50}$ and $\mathrm{CP}_{60}$, respectively, at the expense of $\alpha$-potato starch and squid liver oil (Table 1). The experimental diets were formulated to be isocaloric (16.7 kJ/g energy) based on calculation by Garling and Wilson (1976). The actual nutrient contents in experimental diets are shown in Table 2. The experimental diets preparation and storage have been done following Bai and Kim (1997). In brief, ingredients of the experimental diets were rigorously mixed with a mixer, and then, squid liver oil and EPA \& DHA together with $30 \%$ water were added and further mixed to make a mash. The mashed feeds were finally passed through a laboratory pelleting machine to get 2-mm-diameter pellets. The wet pellets were then stored at $-20{ }^{\circ} \mathrm{C}$ until used.

Fish and husbandry and feeding

Juvenile parrot fish, O. fasciatus were transported from Geoje Marine Hatchery (Geoje, Korea) of National Institute of Fisheries Science (NIFS), Korea to Youngchang Fisheries Farm (Tongyoung, Korea). Before the

Table 1 Composition of the experimental diets (\% of dry matter basis)

\begin{tabular}{lrrrrr}
\hline Ingredients & \multicolumn{2}{l}{ Experimental diets } & & & \\
\cline { 2 - 6 } & $\mathrm{CP}_{35}$ & $\mathrm{CP}_{40}$ & $\mathrm{CP}_{45}$ & $\mathrm{CP}_{50}$ & $\mathrm{CP}_{60}$ \\
\hline White fish meal $^{\mathrm{a}}$ & 28.00 & 30.00 & 32.00 & 34.00 & 25.00 \\
Casein $^{\mathrm{b}}$ & 13.60 & 17.10 & 20.70 & 24.20 & 40.90 \\
a-Potato starch $^{\mathrm{a}}$ & 28.00 & 25.00 & 22.00 & 18.00 & 7.00 \\
Wheat flour $^{\mathrm{c}}$ & 7.00 & 7.00 & 7.00 & 7.39 & 7.00 \\
Squid liver oil $^{\mathrm{d}}$ & 10.31 & 9.21 & 0.06 & 0.40 & 6.40 \\
EPA \& DHA $^{\mathrm{d}}$ & 0.40 & 0.40 & 3.40 & 3.00 & 0.40 \\
Vitamin premix $^{\mathrm{e}}$ & 3.00 & 3.00 & 3.00 & 3.00 & 3.00 \\
Mineral premix $^{\mathrm{f}}$ & 3.00 & 3.00 & 0.05 & 0.05 & 3.00 \\
Vitamin C $^{\mathrm{g}}$ & 0.05 & 0.05 & 1.00 & 1.00 & 0.05 \\
Carboxymethyl cellulose $^{\mathrm{b}}$ & 1.00 & 1.00 & 2.79 & 1.96 & 1.00 \\
Cellulose $^{\mathrm{b}}$ & 5.64 & 4.24 & & 1.05 \\
\hline
\end{tabular}

${ }^{\mathrm{a}}$ Kum Sung Feed Co., Pusan, Korea

${ }^{\mathrm{b}}$ United States Biochemical, Cleveland, Ohio, USA

c Young Nam Flourmills Co., Pusan, Korea

d E-Wha oil Co., Ltd., Pusan, Korea

${ }^{\text {e }}$ Contains (as mg/kg in diets): Ascorbic acid, 300; dl-Calcium pantothenate, 150; Choline bitartrate, 3000; Inositol, 150; Menadione, 6; Niacin, 150; Pyridoxine- $\mathrm{HCl}, 15$; Riboflavin, 30; Thiamine mononitrate, 15; dl- $\alpha$-Tocopherol acetate, 201; Retinyl acetate, 6; Biotin, 1.5; Folic acid, 5.4; $\mathrm{B}_{12}, 0.06$

${ }^{\mathrm{f}}$ Contains (as mg/kg in diet): Al, 1.2; Ca, 5000; Cl, 100; Cu, 5.1; Co, 9.9; Na, 1280; Mg, 520; P, 5000; K, 4300; Zn, 27; Fe, 40.2; I, 4.6; Se, 0.2; Mn, 9.1

g Vitamin C: L-ascorbyl-2-monophosphate, $35 \%$ ascorbic acid activity (Hoffmann-La Roche, Swiss) 
Table 2 Proximate composition of experimental diets (\% of dry matter basis)

\begin{tabular}{lcrrrr}
\hline Items & \multicolumn{2}{l}{ Experimental diets } & & \\
\cline { 2 - 6 } & \multicolumn{1}{c}{$\mathrm{CP}_{35}$} & $\mathrm{CP}_{40}$ & $\mathrm{CP}_{45}$ & $\mathrm{CP}_{50}$ & $\mathrm{CP}_{60}$ \\
\hline Moisture & 27.8 & 26.9 & 27.1 & 26.3 & 28.1 \\
Crude protein & 35.6 & 40.1 & 45.7 & 50.5 & 60.5 \\
Crude lipid & 13.6 & 12.7 & 11.7 & 11.3 & 9.5 \\
Crude ash & 8.5 & 9.6 & 9.5 & 9.9 & 8.6 \\
Estimated energy (kJ/g) & 16.7 & 16.8 & 16.7 & 16.8 & 16.8 \\
P/E ratio (mg/kJ) & 21.3 & 24.1 & 27.4 & 30.2 & 36.2 \\
\hline
\end{tabular}

Values are means of duplicate samples of each diet

start of the experiment, all fish were reared in a circular concrete tank with $5000 \mathrm{~L}$ well water and were fed a commercial diet for 2 weeks. For experimental purposes, 15 floating net cages (each size: $60 \times 40 \times 90 \mathrm{~cm}$, $\mathrm{W} \times \mathrm{L} \times \mathrm{H})$ were installed in a rectangular concrete tank $(5 \times 5 \times 3 \mathrm{~m}, \mathrm{~W} \times \mathrm{L} \times \mathrm{H})$ having flow through system. After a 2-week conditioning period, a group of 20 fish with an average initial weight of $7.1 \pm 0.06 \mathrm{~g}$ (mean $\pm \mathrm{SD}$ ) was randomly distributed into the cages in triplicates according to the five experimental diets.

Fish were fed one of the five isocaloric diets twice (0900 and $1800 \mathrm{~h})$ a day at a level of $4 \%$ of wet body weight in the first 4 weeks and $3 \%$ in the second 4 weeks, respectively, with apparent satiety. Total fish weight in each cage was determined every 2 weeks after anesthesia with 100 ppm of MS 222 (tricaine methanesulfonate), and the amount of feeds were adjusted accordingly. During the experimental period, water flow rate was maintained at $3 \mathrm{~L} / \mathrm{min}$ and water temperature maintained between 19 and $22{ }^{\circ} \mathrm{C}$ due to natural fluctuations in seawater temperature. Supplemental aeration was provided to maintain dissolved oxygen levels near saturation.

Sample collection, analyses and calculations

At the end of the feeding trial, all fish were weighed and counted to calculate growth parameters such as percent weight gain (WG), feed efficiency (FE) and specific growth rate (SGR), feed utilization parameters such as protein efficiency ratio (PER), protein retention efficiency (PRE), energy retention efficiency (ERE), biometrics such as hepatosomatic index (HSI) and condition factor (CF), blood parameters such as hematocrit (percentage of packed cell volume-PCV \%) and hemoglobin ( $\mathrm{Hb}$ ); also, survival rate of juvenile parrot fish was determined (Table 3). After the final weighing, five fish were randomly collected from each aquarium, and blood samples were obtained using heparinized syringes from the caudal vein and pooled in the vials according to the number of diets. Fish blood hematocrit (PCV) was determined by the microhematocrit method (Brown 1980), and hemoglobin ( $\mathrm{Hb}$ ) was measured by the cyanmethemoglobin method using Drabkin's solution. In this study, human blood hemoglobin standard (Sigma-Aldrich, St. Louis, MO, USA) was used for fish blood hemoglobin analysis. Fish liver weight was taken from dissected fish to determine the hepatosomatic index (HSI). Condition factor was measured after collection of fish weight and length data (Table 3). Crude protein, lipid, moisture and ash of whole-body samples were determined by the AOAC methods (1995). In brief, samples of diets and fish were dried to a constant weight at $135^{\circ} \mathrm{C}$ for $2 \mathrm{~h}$ to determine moisture content. Ash was determined by incineration using muffle furnace at $550{ }^{\circ} \mathrm{C}$ for $3 \mathrm{~h}$. Crude lipid was determined by Soxhlet extraction unit using Soxtec system 1046 (Foss, Hoganas, Sweden), and crude protein content was analyzed by Kjeldahl method $(N \times 6.25)$ after acid digestion.

Statistical analysis

All the data were analyzed by one-way ANOVA using SAS version 9.1 software (SAS Institute, Cary, NC, USA) to test the effects of dietary protein (Zar 1984). When a significant effect of the treatments was observed, Duncan's test was used to compare the means. Treatment effects were considered significant at $P<0.05$. Broken-line regression analysis (Robbins et al. 1979) was applied to determine the optimum inclusion level of protein in the diet of juvenile parrot fish. 
Table 3 Growth, feed utilization, biometrics, hematology and survival of juvenile parrot fish Oplegnathus fasciatus fed with five experimental diets for 8 weeks

\begin{tabular}{|c|c|c|c|c|c|}
\hline \multirow[t]{2}{*}{ Items } & \multicolumn{5}{|c|}{ Experimental diets } \\
\hline & $\mathrm{CP}_{35}$ & $\mathrm{CP}_{40}$ & $\mathrm{CP}_{45}$ & $\mathrm{CP}_{50}$ & $\mathrm{CP}_{60}$ \\
\hline $\mathrm{WG}(\%)^{\mathrm{A}}$ & $152 \pm 3.4^{\mathrm{d}}$ & $164 \pm 5.3^{\mathrm{c}}$ & $174 \pm 1.9^{\mathrm{b}}$ & $189 \pm 5.6^{\mathrm{a}}$ & $180 \pm 4.2^{\mathrm{a}}$ \\
\hline $\mathrm{FE}(\%)^{\mathrm{B}}$ & $73.6 \pm 1.3^{\mathrm{b}}$ & $76.3 \pm 3.6^{b}$ & $84.2 \pm 0.9^{\mathrm{a}}$ & $87.6 \pm 2.7^{\mathrm{a}}$ & $86.6 \pm 1.1^{\mathrm{a}}$ \\
\hline $\operatorname{SGR}(\% / \text { day })^{\mathrm{C}}$ & $1.90 \pm 0.03^{\mathrm{b}}$ & $1.94 \pm 0.03^{\mathrm{b}}$ & $2.07 \pm 0.01^{\mathrm{a}}$ & $2.11 \pm 0.04^{\mathrm{a}}$ & $2.12 \pm 0.02^{\mathrm{a}}$ \\
\hline $\mathrm{PER}^{\mathrm{D}}$ & $2.10 \pm 0.04^{\mathrm{a}}$ & $1.74 \pm 0.08^{\mathrm{a}, \mathrm{b}}$ & $1.33 \pm 0.05^{\mathrm{b}}$ & $1.29 \pm 0.01^{\mathrm{b}}$ & $1.22 \pm 0.03^{\mathrm{c}}$ \\
\hline $\operatorname{PRE}(\%)^{\mathrm{G}}$ & $35.3 \pm 4.1^{\mathrm{a}}$ & $34.1 \pm 2.6^{\mathrm{a}}$ & $30.1 \pm 3.1^{\mathrm{a}, \mathrm{b}}$ & $29.0 \pm 3.7^{\mathrm{a}, \mathrm{b}}$ & $25.3 \pm 3.1^{\mathrm{b}}$ \\
\hline $\operatorname{ERE}(\%)^{\mathrm{H}}$ & $34.8 \pm 2.8^{\mathrm{b}}$ & $36.5 \pm 2.3^{\mathrm{a}, \mathrm{b}}$ & $40.8 \pm 3.1^{\mathrm{a}}$ & $40.9 \pm 2.4^{\mathrm{a}}$ & $38.5 \pm 3.4^{\mathrm{a}}$ \\
\hline $\mathrm{HSI}^{\mathrm{E}}$ & $3.42 \pm 0.09^{\mathrm{a}}$ & $3.18 \pm 0.06^{\mathrm{a}, \mathrm{b}}$ & $3.01 \pm 0.09^{\mathrm{b}}$ & $3.09 \pm 0.06^{\mathrm{b}}$ & $2.88 \pm 0.05^{\mathrm{b}}$ \\
\hline $\mathrm{CF}^{\mathrm{F}}$ & $2.57 \pm 0.06^{\mathrm{b}}$ & $2.56 \pm 0.04^{\mathrm{b}}$ & $2.77 \pm 0.03^{\mathrm{a}}$ & $2.73 \pm 0.03^{\mathrm{a}}$ & $2.78 \pm 0.07^{\mathrm{a}}$ \\
\hline Hematocrit (\%) & $30.1 \pm 1.6^{\mathrm{a}, \mathrm{b}}$ & $32.1 \pm 1.9^{\mathrm{a}}$ & $33.3 \pm 1.2^{\mathrm{a}}$ & $29.9 \pm 1.4^{\mathrm{b}}$ & $31.5 \pm 1.5^{\mathrm{a}}$ \\
\hline Hemoglobin $(\mathrm{g} / \mathrm{dl})$ & $6.1 \pm 0.8^{\mathrm{b}}$ & $6.7 \pm 0.3^{\mathrm{a}}$ & $6.5 \pm 0.2^{\mathrm{a}, \mathrm{b}}$ & $7.3 \pm 0.4^{\mathrm{a}}$ & $7.0 \pm 0.6^{\mathrm{a}}$ \\
\hline Survival rate $(\%)$ & $98.3 \pm 2.9$ & 100 & 100 & 100 & $98.3 \pm 2.9$ \\
\hline
\end{tabular}

Values are means from triplicate groups of fish where the means in each row with a different superscript are significantly different $(P<0.05)$

A Percent weight gain: (final wt. - initial wt.) $\times 100 /$ initial wt

${ }^{B}$ Feed efficiency: (wet weight gain/dry feed intake) $\times 100$

C Specific growth rate: $100 \times($ ln final wt. $-\ln$ initial wt. $) /$ days

D Protein efficiency ratio: (wet weight gain/protein intake) $\times 100$

${ }^{\mathrm{E}}$ Hepatosomatic index: (liver weight/body weight) $\times 100$

F Condition factor: [fish wt. (g)/fish length $\left.(\mathrm{cm})^{3}\right] \times 100$

G Protein retention efficiency: [(final total body protein - initial total body protein)/total dietary protein fed] $\times 100$

${ }^{\mathrm{H}}$ Energy retention efficiency: [(final total body energy - initial total body energy)/total dietary energy fed] $\times 100$

\section{Results}

Growth performance of parrot fish fed with experimental diets at different protein levels for 8 weeks is shown in Table 3. At the end of feeding trial, $\mathrm{WG}$ of fish fed with $\mathrm{CP}_{50}$ and $\mathrm{CP}_{60}$ diets were significantly higher than those of fish fed with $\mathrm{CP}_{35}, \mathrm{CP}_{40}$ and $\mathrm{CP}_{45}$ diets $(P<0.05)$. However, there were no significant differences in WG between fish fed with $\mathrm{CP}_{50}$ and $\mathrm{CP}_{60}$ diets. Fish fed with $\mathrm{CP}_{45}, \mathrm{CP}_{50}$ and $\mathrm{CP}_{60}$ diets showed higher $\mathrm{FE}$ and SGR than those of fish fed with $\mathrm{CP}_{35}$ and $\mathrm{CP}_{40}$ diets. In contrast to WG, FE and SGR, protein efficiency ratio (PER) and protein retention efficiency (PRE) decreased with increasing dietary protein levels. The highest and the lowest ERE values were observed in fish fed with $\mathrm{CP}_{50}$ and $\mathrm{CP}_{35}$ diets, respectively. Hepatosomatic index (HSI) was highest in fish fed with $\mathrm{CP}_{35}$ diet, whereas lowest HSI was observed in fish fed with $\mathrm{CP}_{60}$ diet. Condition factor (CF) followed the same trend as FE and SGR of fish fed with the experimental diets. No significant differences were found in survival rate of fish fed with the diets.

In considering hematological characteristics of fish, juvenile parrot fish fed with the $\mathrm{CP}_{35}$ diet showed significantly lower hemoglobin levels than those of the fish fed with $\mathrm{CP}_{40}, \mathrm{CP}_{50}$ and $\mathrm{CP}_{60}$ diets $(P<0.05)$. Blood hematocrit level was lower in fish fed with the $\mathrm{CP}_{50}$ diet than those of the fish fed with $\mathrm{CP}_{40}, \mathrm{CP}_{45}$ and $\mathrm{CP}_{60}$ diets $(P<0.05)$.

Whole-body proximate composition of juvenile parrot fish is shown in Table 4. The table showed that crude protein $(\mathrm{CP})$ and crude lipid (CL) content in whole body increased with the increase in dietary protein levels. Significantly higher whole-body $\mathrm{CP}$ and moisture contents were found in fish fed with $\mathrm{CP}_{50}$ and $\mathrm{CP}_{60}$ diets than those of the fish fed with $\mathrm{CP}_{35}$ and $\mathrm{CP}_{40}$ diets. Whole-body $\mathrm{CL}$ content was found to be highest in fish fed with $\mathrm{CP}_{50}$ diet and lowest in fish fed with $\mathrm{CP}_{35}$ diet. No significant differences were found in fish fed with the experimental diets in terms of whole-body ash contents.

Broken-line analysis of weight gain indicated that the optimum dietary protein level was $48.5 \%$ in juvenile parrot fish (Fig. 1). 
Table 4 Proximate composition (\%) of the whole body of juvenile parrot fish Oplegnathus fasciatus fed with five experimental diets for 8 weeks

\begin{tabular}{|c|c|c|c|c|}
\hline Experimental diets & Moisture & Crude protein & Crude lipid & Crude ash \\
\hline $\mathrm{CP}_{35}$ & $66.8 \pm 0.5^{\mathrm{a}}$ & $15.8 \pm 0.2^{\mathrm{c}}$ & $8.7 \pm 0.3^{\mathrm{b}}$ & $4.5 \pm 0.3$ \\
\hline $\mathrm{CP}_{40}$ & $67.1 \pm 0.7^{\mathrm{a}}$ & $16.2 \pm 0.3^{\mathrm{b}}$ & $9.3 \pm 0.2^{\mathrm{a}}$ & $4.3 \pm 0.1$ \\
\hline $\mathrm{CP}_{45}$ & $66.3 \pm 1.0^{\mathrm{a}, \mathrm{b}}$ & $16.6 \pm 0.1^{\mathrm{a}, \mathrm{b}}$ & $9.2 \pm 0.1^{\mathrm{a}, \mathrm{b}}$ & $4.2 \pm 0.2$ \\
\hline $\mathrm{CP}_{50}$ & $66.1 \pm 0.5^{\mathrm{b}}$ & $17.1 \pm 1.0^{\mathrm{a}}$ & $9.6 \pm 0.4^{\mathrm{a}}$ & $4.2 \pm 0.3$ \\
\hline $\mathrm{CP}_{60}$ & $65.6 \pm 0.5^{\mathrm{b}}$ & $16.9 \pm 0.1^{\mathrm{a}}$ & $9.0 \pm 0.3^{\mathrm{a}, \mathrm{b}}$ & $4.1 \pm 0.3$ \\
\hline
\end{tabular}

Values are means from triplicate groups of fish where the means in each column with a different superscript are significantly different $(P<0.05)$

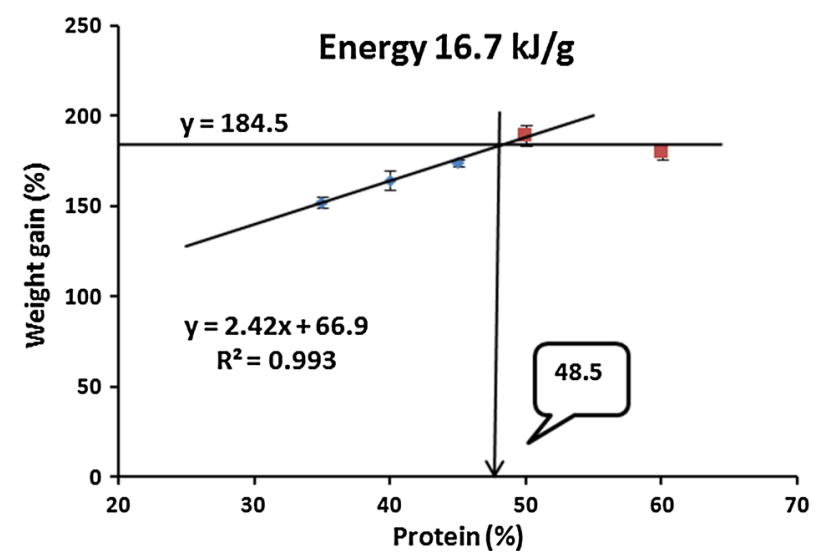

Fig. 1 Broken-line model of percent weight gain in parrot fish fed with five different levels of dietary protein for 8 weeks

\section{Discussion}

After 8 weeks of the feeding trial, ANOVA showed that WG of fish fed with the $50 \% \mathrm{CP}$ diet was significantly higher than those of fish fed with the 35 and $40 \%$ CP diets; however, there was no significant difference between fish fed with the 50 and $60 \%$ CP diets (Table 3). Based on broken-line analysis of WG of parrot fish, the optimum dietary protein was $48.5 \%$. Similarly, Hossain et al. (2010) reported that the optimum dietary protein level for silver pomfret, Pampus argenteus, was $49 \% \mathrm{CP}$. In line with our result, protein requirement of some other fish species such as in Olive flounder, Paralichthys olivaceus was found to be $46.4 \%$ (Kim et al. 2002), $47.8 \%$ for grouper, Epinephelus malabaricus (Chen and Tsai 1994). Generally, when dietary protein levels increase, growth of fishes also increases (NRC 1993). In this experiment, WG, FE, SGR and CF of fish improved with increasing dietary protein levels up to $50 \% \mathrm{CP}$; then, no further improvements were observed in these parameters at higher protein levels (Table 2).

In the present study, PER and PRE decreased with increase of protein level in the treatment groups (Table 3). The result shows that, possibly, dietary protein was efficiently utilized by fish for protein synthesis which is in accordance with Berger and Halver (1987). Similar results have been reported in other fish species (Bai et al. 1999; Kim et al. 2004, 2005; Hossain et al. 2010; Zhang et al. 2010). In contrast to our study, Kikuchi et al. (1992) and Lee et al. (2000) reported that PER values of olive flounder increased with increasing dietary protein levels. However, Dabrowski (1979) reported that the relationship between dietary protein and PER differs from species to species. In the present study, ERE increased with the increase of dietary protein levels which means dietary protein could be spared by non-protein energy sources. Dietary protein sparing helps to reduce feed cost and nitrogen waste outputs (Wang et al. 2006). Ng et al. (2008) reported that lipid plays an important role for protein sparing when dietary protein level is low in relation to the requirement which might be reflected in our experiment as well. 
Hematological parameters such as hemoglobin $(\mathrm{Hb})$ and hematocrit $(\mathrm{PCV})$ concentration levels were affected by dietary protein levels (Table 3). Higher level of $\mathrm{Hb}$ and lower level PCV were found in blood of fish fed with $50 \%$ CP diet compared with other experimental diets which may indicate the healthy condition of fish. However, Kim et al. (2004) found that dietary protein levels have no significant effect on hematological and serological characteristics of juvenile Korean rockfish.

Fish biometrics in terms of hepatosomatic index (HSI) and condition factor (CF) indicate the body condition of fish. In this study, HSI was decreased and CF was increased with protein level increment in the diets which may indicate the higher utilization of protein levels from the diets by fish. These results are in agreement with Kim and Lall (2001). Survival rate was not significantly affected among fish fed with the experimental diets.

Proximate composition in terms of ash contents of fish fed with the experimental diets was not significantly affected by dietary protein levels (Table 4) which are in accordance with Okorie et al. (2007) for juvenile Japanese eel and Kim et al. (2004) for Korean rockfish. In this experiment, the whole-body CP content increased with the increasing dietary protein levels which agree with the results found by Kim et al. (2002). Similarly, the body lipid content generally increased as the dietary protein level increased which is in agreement with Shiau and Lan (1996) for grouper and Bai et al. (1999) for yellow puffer. On the contrary, Kim et al. (2002) reported that as the CP content of whole body increases, whole-body CL content decreases.

In fine, based on the broken-line analysis of weight gain, it can be corroborated that the optimum dietary protein level for juvenile parrot fish could be $48.5 \%$ for its maximum growth at the gross energy level of $16.7 \mathrm{~kJ} / \mathrm{g}$ diet.

Acknowledgments This research was supported by a Grant (R2016016) from the National Institute of Fisheries Science (NIFS) and Feeds and Foods Nutrition Research Center (FFNRC) at Pukyong National University, Republic of Korea.

\section{Compliance with ethical standards}

Conflict of interests The authors declare that there are no competing interests.

Open Access This article is distributed under the terms of the Creative Commons Attribution 4.0 International License (http:// creativecommons.org/licenses/by/4.0/), which permits unrestricted use, distribution, and reproduction in any medium, provided you give appropriate credit to the original author(s) and the source, provide a link to the Creative Commons license, and indicate if changes were made.

\section{References}

Association of Official Analytical Chemists (AOAC) (1995) Official methods of analysis. Association of Official Analytical Chemists Inc, Arlington

Bai SC, Kim KW (1997) Effects of dietary animal protein sources on growth and body composition in Korean rockfish, Sebastes schlegeli. J Aqua 10:77-85 (In Korean with English abstract)

Bai SC, Wang XJ, Cho ES (1999) Optimum dietary protein level for maximum growth of juvenile yellow puffer. Fish Sci 65:380-383

Berger A, Halver JE (1987) Effect of dietary protein, lipid and carbohydrate content on the growth, feed efficiency and carcass composition of striped bass, Morone saxatilis (Walbaum) fingerlings. Aqua Fish Manage 18:345-356

Brown BA (1980) Hematology: principles and procedures. Lea and Febiger, Philadelphia

Chen HY, Tsai JC (1994) Optimum dietary protein level for the growth of juvenile grouper, Epinephelus malabaricus, fed semipurified diets. Aquaculture 119:265-271

Dabrowski K (1979) Feeding requirement of fish with particular attention to common carp: a review. Polish Arch Hydrobiol 26:135-158

Garling DI, Wilson RP (1976) Optimum dietary protein to energy ratio for channel catfish fingerlings, Ictalurus punctatus. J Nutr 106:1368-1375

Hepher B (1988) Nutrition of pond fishes. Cambridge University Press, Sydney

Hossain MA, Almatar SM, James CM (2010) Optimum dietary protein level for juvenile silver pomfret, Pampus argenteus (Euphrasen). J World Aqua Soc 41:710-720

Kikuchi K, Sugita H, Watanabe T (1992) Effect of dietary protein level on growth and body composition of Japanese flounder, Paralichthys olivaceus. Suisanzoshoku 40:335-340

Kim JD, Lall SP (2001) Effects of dietary protein level on growth and utilization of protein and energy by juvenile haddock (Melanogrammus aeglefinus). Aquaculture 195:311-319

Kim KW, Wang XJ, Bai SC (2002) Optimum dietary protein level for maximum growth of juvenile olive flounder, Paralichthys olivaceus (Temminck et Schlegel). Aqua Res 33:673-679 
Kim KW, Wang XJ, Han K, Kang JC, Bai SC (2004) Optimum dietary protein level and protein-to-energy ratio for growth of juvenile Korean rockfish Sebastes schlegeli. J World Aqua Soc 35:305-314

Kim KW, Kang YJ, Choi SM, Wang XJ, Choi YH, Bai SC, Lee JY, Jo JY (2005) Optimum dietary protein levels and protein to energy ratios in Olive flounder Paralichthys olivaceus. J World Aqua Soc 36:165-178

Lee SM, Cho SH, Kim KD (2000) Effects of dietary protein and energy levels on growth and body composition of juvenile flounder, Paralichthys olivaceus. J World Aqua Soc 36:165-178

Meng QW, Su JX, Miao XZ (1995) Fish taxonomy. China Agriculture Press, Beijing, pp 734-756

Mohseni M, Pourkazemi M, Hosseni MR, Hassani MHS, Bai SC (2013) Effects of the dietary protein levels and the protein to energy ratio in sub-yearling Persian sturgeon, Acipenser persicus (Borodin). Aquacult Res 44:378-387

National Research Council (NRC) (1993) Nutrient requirements of fish. National Academy Press, Washington

National Research Council (NRC) (2011) Nutrient requirements of fish and shrimp. National Academy Press, Washington

National Statistical Office (2015) Survey on the status of fish culture. National Statistical Office, Daejeon

Ng WK, Abdullah N, De Silva SS (2008) The dietary protein requirement of the Malaysian mahseer, Tor tambroides (Bleeker), and the lack of protein-sparing action by dietary lipid. Aquaculture 284:201-206

Okorie EO, Kim YC, Lee S, Bae JY, Yoo JH, Han K, Park GJ, Choi SM, Bai SC (2007) Reevaluation of the dietary protein requirements and optimum dietary protein to energy ratios in Japanese eel, Anguilla japonica. J World Aqua Soc 38:418-426

Robbins KR, Norton HW, Baker DH (1979) Estimation of nutrient requirements from growth data. J Nutr 109:1710-1714

Shiau SY, Lan CW (1996) Optimum dietary protein level and protein to energy ratio for growth of grouper (Epinephelus malabaricus). Aquaculture 145:259-266

Wang Y, Guo J, Li K, Bureau DP (2006) Effects of dietary protein and energy levels on growth, feed utilization and body composition of cuneate drum, Nibea miichthioides. Aquaculture 252:421-428

Zar JH (1984) Biostatistical analysis, 2nd edn. Prentice-Hall International Inc, Englewood Cliffs, New Jersey

Zhang J, Zhou F, Wang LL, Shao Q, Xu Z, Xu J (2010) Dietary protein requirement of juvenile black sea bream, Sparus macrocephalus. J World Aqua Soc 41:151-164 